\title{
Cromolyn Sodium Decreases the Pulmonary Vascular Response to Alveolar Hypoxia in Lambs
}

\author{
BONNIE J. TAYLOR, JAMES E. FEWELL, GREGORY L. KEARNS, AND DONALD E. HILL \\ Perinatal Research Laboratory, Departments of Pediatrics, Physiology, and Pharmaceutics, University of \\ Arkansas for Medical Sciences, Little Rock, Arkansas 72205
}

\begin{abstract}
We investigated the effect of cromolyn sodium, a mast cell stabilizing agent, on the pulmonary vascular response to alveolar hypoxia in six chronically instrumented lambs aged 9 to 11 days. Each lamb was instrumented on day 6 or 7 for measurements of systemic arterial, pulmonary arterial and left atrial pressures, and pulmonary blood flow. The animals were allowed to recover from surgery at least 3 days before they were studied. Each animal was studied twice, once with a cromolyn sodium infusion and once with a normal saline infusion (placebo). These paired experiments were separated by $24 \mathrm{~h}$. Physiologic measurements were made during a 1-min predose control period, after an 8-min drug or placebo infusion, and after a 15-min period of alveolar hypoxia. Cromolyn sodium infusion alone did not affect baseline cardiovascular variables. Alveolar hypoxia following placebo infusion produced an increase in pulmonary arterial pressure and pulmonary vascular resistance; these responses were blocked in the animals given cromolyn sodium prior to induction of hypoxia. These results show that cromolyn sodium blocks the pulmonary vascular response to hypoxia and provide indirect evidence that mast cell degranulation, with subsequent release of vasoactive agents, mediates the pulmonary vascular response to hypoxia in newborn lambs. (Pediatr Res 20: 834-837, 1986)
\end{abstract}

It is known that alveolar hypoxia produces pulmonary vasoconstriction $(1,2)$, but the exact mechanism underlying this physiologic response remains unknown. Perivascular tissue is needed to produce hypoxic pulmonary vasoconstriction in isolated pulmonary arteries, suggesting an indirect effect of hypoxia on parenchymal tissue rather than a direct effect on vascular smooth muscle (3). Mast cells are present in large numbers in pulmonary perivascular tissue (4), placing them in an ideal location to influence vascular tone.

Mast cell degranulation has been demonstrated following acute alveolar hypoxia in rats (4) and sheep (5). If alveolar hypoxia causes release of mast cell mediators which promote vasoconstriction, pharmacologic inhibition of degranulation should prevent hypoxic pulmonary vasoconstriction. Indeed, Ahmed et al. (5) have shown that administration of cromolyn sodium-a mast cell stabilizing agent (6)-blocks pulmonary vasoconstriction during alveolar hypoxia in adult sheep. The role of mast cells in mediating hypoxic pulmonary vasoconstriction in newborn animals or humans is unknown. Because pulmonary vasoconstric-

Received August 16, 1985; accepted April 17, 1986.

Address correspondence to Bonnie J. Taylor, M.D. University of Arkansas for Medical Sciences, 4301 West Markham Street, Little Rock, AR 72205.

Supported in part by an Institutional Study Grant from the University of Arkansas for Medical Sciences, College of Medicine. J.E.F. is an Established Investigator of the American Heart Association. tion is accentuated in newborns $(7,8)$ and may involve additional mechanisms not present in adults, we chose to investigate the effect of cromolyn sodium on the pulmonary vascular response to hypoxia in newborn lambs.

\section{METHODOLOGY}

Six lambs $(5.1 \pm 0.9 \mathrm{~kg})$ were studied between 9-11 days of age. The animals were housed in separate plexiglass cages with continuous access to an artificial lamb's milk diet (Lamb Milk Replacer, Land O'Lakes, Inc. Fort Dodge, IA). All animals were healthy, eating well, and gaining weight at the time of study. Lambs of both sexes were used for study.

\section{SURGICAL PREPARATION}

Each lamb underwent one sterile operation at 6-7 days of age. Following an overnight fast, the animals were given atropine sulfate $(0.2 \mathrm{mg} / \mathrm{kg}$ subcutaneously) and ketamine $\mathrm{HCl}(10 \mathrm{mg} /$ $\mathrm{kg}$ intramuscularly). Each animal's trachea was intubated with a cuffed endotracheal tube and the cuff inflated to a gas-tight fit. Inhalation anesthesia was maintained by ventilating the lungs with 1.0-2.0\% halothane (Fluothane, Ayerst Laboratories, New York, NY) in oxygen and nitrous oxide (3:1). The electrocardiogram and rectal temperature were continuously monitored during surgery; core temperature was maintained at or near $39^{\circ}$ $\mathrm{C}$ during the surgical procedure with a heating pad.

A midline sternotomy was performed to expose the heart and great vessels. The pericardium was incised and a precalibrated electromagnetic flow transducer (SP 7515, I.D. 9.0-10.0 mm, Gould-Statham, Inc., Oxnard, CA) was placed around the main pulmonary artery to measure pulmonary blood flow. A polyvinyl chloride catheter treated with TDMAC heparin complex $(5 \%)$ (Polysciences Inc., Warrington, PA) was inserted into the main pulmonary artery distal to the flow transducer to measure pulmonary arterial pressure. A second catheter was inserted into the left atrial appendage for measurement of left atrial pressure. Additional catheters were placed into the femoral artery and vein, and advanced into the descending aorta and inferior vena cava, respectively, to measure systemic arterial pressure and arterial blood gases, and for infusion of cromolyn sodium or placebo.

All catheters and the flow transducer cable were tunneled subcutaneously to and exteriorized on the lamb's back. A daily intramuscular dose of antibiotics (procaine penicillin G 100,000 $\mathrm{U} / \mathrm{kg}$ and gentamicin sulfate $2 \mathrm{mg} / \mathrm{kg}$ ) was administered before surgery and each day postoperatively. The animals were allowed to recover for at least 3 days before they were studied.

\section{DRUG PREPARATION}

Cromolyn sodium, analytical grade (Fisons Corporation, Bedford, MA), $1.5 \mathrm{~g}$, was weighed on an analytical balance. The drug was dissolved in $50.0 \mathrm{ml}$ of $0.9 \% \mathrm{NaCl}$ without preservatives for 
injection (Travenol Laboratories, Inc., Deerfield, IL) with continuous stirring at $37^{\circ} \mathrm{C}$ for $10 \mathrm{~min}$. The resultant solution was passed through a $0.22-\mu$ air eliminating membrane filter (Travenol Laboratories, Inc.) and injected into a $30.0-\mathrm{ml}$ sterile, pyrogen-free glass vial (Elkins Sinn, Inc., Cherry Hill, NJ). The final sterile solution of cromolyn sodium $(30 \mathrm{mg} / \mathrm{ml})$ was protected from light and stored at $4^{\circ} \mathrm{C}$ for a period not exceeding $12 \mathrm{~h}$ from preparation. For each experiment, a fresh solution of cromolyn sodium was prepared.

\section{EXPERIMENTAL DESIGN}

For study, each animal was secured in a sling, and a plastic bag into which $21 \% \mathrm{O}_{2}$ was flowing was placed over the lamb's head and secured with a drawstring. The vascular catheters were connected to strain gauge manometers (Statham P23Db) using rigid pressure monitoring tubing (American Pharmaseal, PP148, 48 inches long). The height of the manometers was adjusted to place them at the level of the heart. The flow transducer cable was connected to a flow meter (Statham SP2202, Gould-Statham, Inc.).

During a study, pulmonary blood flow and pulmonary arterial, systemic arterial and left atrial pressures were monitored continuously on an Electronics for Medicine DR-12 recorder. Recordings were made during a 1-min control period while the animal was awake, resting quietly, and breathing $21 \% \mathrm{O}_{2}$. A continuous intravenous infusion of cromolyn sodium $(3 \mathrm{mg} / \mathrm{kg} / \mathrm{min})$ or normal saline was then begun and a second recording made at the end of an 8-min infusion period. Alveolar hypoxia $\left(10 \% \mathrm{O}_{2}\right.$, $5 \% \mathrm{CO}_{2}, 85 \% \mathrm{~N}_{2}$ ) was then immediately induced as the drug or saline infusion was continued. A third recording was made at the end of $15 \mathrm{~min}$ of hypoxia. The gas mixture was then switched to $21 \% \mathrm{O}_{2}$, the drug or saline infusion was discontinued, and the animal allowed to recover. Arterial blood gas samples were obtained during the control period, after the 8-min prehypoxia drug infusion, and following $15 \mathrm{~min}$ of hypoxia.

Each animal was studied twice; once with a placebo (normal saline) and once with cromolyn sodium. These paired experiments were separated by $24 \mathrm{~h}$ and the sequence of placebo and cromolyn administration was alternated between animals, permitting each animal to serve as his own control.

\section{STATISTICAL ANALYSIS}

Data are expressed as means $\pm 1 \mathrm{SD}$. We tested the null hypothesis that the cardiovascular response to alveolar hypoxia is not affected by pretreatment with cromolyn sodium. Statistical analysis was done using a one-way analysis of variance for repeated measures of the same variable (9). If a significant difference $(p<0.05)$ was found, a Newman-Keuls multiple range test was done to determine which values were different from one another (10).

\section{RESULTS}

Alveolar hypoxia produced similar changes in arterial blood gases and $\mathrm{pH}$ during infusion of placebo and cromolyn sodium (Table 1). Infusion of cromolyn sodium did not significantly affect any cardiovascular or blood gas variables compared to infusion of placebo during normoxemia (Table 2).

Alveolar hypoxia produced a $44 \%$ increase in pulmonary arterial pressure following infusion of placebo; this increase was primarily due to an increase in pulmonary vascular resistance. Pulmonary arterial pressure increased $3 \%$ and pulmonary vascular resistance did not change during alveolar hypoxia following infusion of cromolyn sodium. Alveolar hypoxia produced no significant changes in systemic arterial pressure, systemic vascular resistance, or left atrial pressure in either group.

A slight increase in cardiac output during alveolar hypoxia occurred in both groups and appeared to result from different mechanisms. Following infusion of placebo, the increase in cardiac output during alveolar hypoxia (14\% from baseline) resulted entirely from an increase in heart rate. However, following infusion of cromolyn sodium, the increase in cardiac output during alveolar hypoxia ( $9 \%$ from baseline) resulted from an increase in heart rate and stroke volume.

\section{DISCUSSION}

These results demonstrate that parenteral cromolyn sodium prevents pulmonary vasoconstriction induced by acute alveolar hypoxia in the lamb without altering the peripheral vascular response. Ahmed et al. (5) have suggested that cromolyn sodium exerts this effect in adult sheep by a pharmacologic blockade of mast cell degranulation. The mechanism of mast cell degranulation is not fully understood but is probably related to an influx of extracellular calcium ions into the mast cell, a process thought to be inhibited by cromolyn sodium $(6,11)$. Cromolyn sodium inhibits the release of mast cell mediators in both in vitro and in vivo systems and has no intrinsic bronchodilator or antiinflammatory activity $(6,12)$. In addition, cromolyn sodium has not shown any antagonistic activity against histamine, bradykinin, serotonin, acetylcholine, prostaglandins, or leukotrienes in isolated tissue or anesthetized guinea pigs (12). Cromolyn sodium also failed to modify the pulmonary pressor response to histamine, norepinephrine, and tyramine in conscious sheep (5), findings supporting a lack of specific antagonistic effect on vascular smooth muscle or $\alpha$-blocking properties.

The mechanism for the slight increase in cardiac output during alveolar hypoxia appears to be related to heart rate alone in the placebo group and to a slight increase in both heart rate and stroke volume in the cromolyn sodium group. Ahmed and coworkers found a larger increase in cardiac output during alveolar hypoxia in their sheep receiving cromolyn sodium (5) or a leukotriene receptor blocker (FPL 57231) (13) compared to infusion of placebo. They did not report heart rate or stroke volume data, so the mechanism of this change in cardiac output is not known. Leffler et al. (14) noted a significant dose-dependent fall in cardiac output in newborn piglets infused with leukotriene $\mathrm{D}_{4}$; this change was blocked by the leukotriene receptor antagonist FPL 55712. Heart rate did not change significantly, implying a decrease in stroke volume. Since mast cells contain leukotrienes, we can speculate that if cromolyn sodium blocks mast cell degranulation, this may protect the heart from the negative inotropic effects of the leukotrienes and allow an in-

Table 1. Arterial blood gas values in placebo and cromolyn sodium groups (mean $\pm 1 S D$ )*

\begin{tabular}{ccccccc}
\hline & Baseline & $\begin{array}{c}\text { Placebo group } \\
\text { drug infusion }\end{array}$ & Hypoxia & Baseline & $\begin{array}{c}\text { Cromolyn group } \\
\text { drug infusion }\end{array}$ & Hypoxia \\
\hline $\mathrm{pH}$ & $7.39 \pm 0.04$ & $7.40 \pm 0.01$ & $7.33 \pm 0.05 \dagger$ & $7.41 \pm 0.02$ & $7.39 \pm 0.02$ & $7.32 \pm 0.06 \dagger$ \\
$\mathrm{PO}_{2}$ & $59 \pm 11$ & $65 \pm 18$ & $36 \pm 10 \ddagger$ & $66 \pm 7$ & $62 \pm 13$ & $39 \pm 13 \ddagger$ \\
$\mathrm{PCO}_{2}$ & $44 \pm 2$ & $38 \pm 4$ & $45 \pm 5$ & $39 \pm 5$ & $40 \pm 8$ & $45 \pm 4$ \\
\hline
\end{tabular}

* Baseline and drug infusion values were obtained while breathing $21 \% \mathrm{O}_{2}$. Hypoxia values were obtained while breathing $10 \% \mathrm{O}_{2}$ and $5 \% \mathrm{CO}_{2}$. All results are corrected to a body temperature of $39^{\circ} \mathrm{C}$.

$\dagger p<0.025$ from postdrug values in both groups.

$\ddagger p<0.001$ from postdrug values in both groups. 
Table 2. Hemodynamic changes with placebo and cromolyn sodium infusion (mean $\pm S D$ )*

\begin{tabular}{|c|c|c|c|c|c|c|}
\hline & \multicolumn{3}{|c|}{ Placebo } & \multicolumn{3}{|c|}{ Cromolyn sodium } \\
\hline & Normoxia & $\begin{array}{l}\text { Post drug } \\
\text { infusion }\end{array}$ & Hypoxia & Normoxia & $\begin{array}{l}\text { Post drug } \\
\text { infusion }\end{array}$ & Hypoxia \\
\hline $\begin{array}{l}\text { Pulmonary arterial pres- } \\
\text { sure }(\mathrm{mm} \mathrm{Hg})\end{array}$ & $27 \pm 8$ & $28 \pm 9$ & $39 \pm 8 \dagger$ & $28 \pm 8$ & $30 \pm 7$ & $31 \pm 9 \ddagger$ \\
\hline $\begin{array}{l}\text { Pulmonary vascular resist- } \\
\text { ance (U) }\end{array}$ & $0.06 \pm 0.04$ & $0.07 \pm 0.03$ & $0.10 \pm 0.03 \S$ & $0.07 \pm 0.03$ & $0.07 \pm 0.03$ & $0.07 \pm 0.04 \|$ \\
\hline $\begin{array}{l}\text { Systemic arterial pressure } \\
(\mathrm{mm} \mathrm{Hg})\end{array}$ & $74 \pm 3$ & $75 \pm 4$ & $82 \pm 10$ & $75 \pm 8$ & $72 \pm 10$ & $77 \pm 8$ \\
\hline $\begin{array}{l}\text { Systemic vascular resist- } \\
\text { ance }(U)\end{array}$ & $0.22 \pm 0.03$ & $0.23 \pm 0.04$ & $0.22 \pm 0.06$ & $0.25 \pm 0.05$ & $0.23 \pm 0.06$ & $0.22 \pm 0.03$ \\
\hline $\begin{array}{l}\text { Cardiac output }\left(\mathrm{ml} \cdot \mathrm{kg}^{-1} \text {. }\right. \\
\left.\min ^{-1}\right)\end{array}$ & $328 \pm 35$ & $331 \pm 49$ & $373 \pm 78$ & $319 \pm 62$ & $329 \pm 63$ & $347 \pm 51$ \\
\hline Heart rate (bpm) & $213 \pm 34$ & $213 \pm 39$ & $245 \pm 60$ 9 & $221 \pm 43$ & $210 \pm 42$ & $214 \pm 62^{* *}$ \\
\hline $\begin{array}{l}\text { Left atrial pressure }(\mathrm{mm} \\
\mathrm{Hg} \text { ) }\end{array}$ & $8.4 \pm 4.7$ & $7.2 \pm 3.7$ & $5.2 \pm 1.5$ & $6.2 \pm 2.2$ & $7.0 \pm 2.2$ & $6.8 \pm 0.8$ \\
\hline Stroke volume $\left(\mathrm{ml} \cdot \mathrm{kg}^{-1}\right)$ & $1.6 \pm 0.2$ & $1.6 \pm 0.2$ & $1.6 \pm 0.4$ & $1.5 \pm 0.4$ & $1.6 \pm 0.4$ & $1.8 \pm 0.4$ \\
\hline \multicolumn{7}{|c|}{$\begin{array}{l}* n=6 ; \mathrm{U}: \mathrm{mm} \mathrm{Hg} \cdot \mathrm{ml}^{-1} \cdot \mathrm{kg}^{-1} \cdot \mathrm{min}^{-1} \\
\dagger p<0.001 \text { vs postdrug. } \\
\ddagger p<0.001 \text { vs placebo. } \\
\S p<0.005 \text { vs postdrug. } \\
\| p<0.005 \text { vs placebo. } \\
\text { I } p<0.05 \text { vs postdrug. } \\
{ }_{* *} p<0.025 \text { vs placebo. }\end{array}$} \\
\hline
\end{tabular}

crease in cardiac output during alveolar hypoxia by increased contractility and stroke volume. As an alternative explanation, cromolyn sodium itself might directly enhance stroke volume by a mechanism not yet understood.

Most reports of the effects of cromolyn sodium on the pulmonary vascular response to hypoxia have been studies performed on anesthetized adult animals. Rengo et al. (15) demonstrated that cromolyn sodium inhibited hypoxic pulmonary vasoconstriction and blocked hypoxia-induced increases in histamine levels in dogs. Kay and Grover (16) reported a variable response to cromolyn sodium in acutely hypoxic dogs, noting inhibition of pulmonary vasoconstriction in only three of eight animals. Doherty et al. (17) perfused isolated guinea pig lungs with cromolyn sodium prior to induction of alveolar hypoxia and blunted histamine release, a marker for mast cell degranulation (4). Ahmed et al. (5) demonstrated in conscious sheep that cromolyn sodium blunted vasoconstriction induced by acute alveolar hypoxia but did not reverse vasoconstriction when administered after hypoxia was established. They further demonstrated mast cell degranulation histologically after acute exposure to $10 \% \mathrm{O}_{2}$, but no degranulation was seen with cromolyn sodium pretreatment.

The perivascular and perialveolar locations of mast cells in the lung are ideal for monitoring alveolar oxygen tension and releasing mediators near the pulmonary microcirculation in response to hypoxia. However, some studies do not support mast cell degranulation as a contributor to hypoxic pulmonary vasoconstriction. Martin et al. (18) noted an inverse relationship between lung mast cell density and the pulmonary pressor response to acute alveolar hypoxia in cats treated with radiation and nitrogen mustard to decrease mast cell numbers, suggesting that mast cells oppose rather than promote hypoxic pulmonary hypertension. Zhu et al. (19) reported that mast cell-deficient mice develop pulmonary hypertension identical to that of normal mice when chronically exposed to $10 \% \mathrm{O}_{2}$ and concluded that mast cells do not contribute at all to the pulmonary vascular response to hypoxia.

The contribution of mast cell degranulation to hypoxic pulmonary vasoconstriction in the human neonate is not known. The leukotrienes are thought to play a role in sustaining high pulmonary vascular resistance because leukotriene receptor blockers decrease pulmonary vascular resistance in newborn lambs (20) and in adult sheep (13) subjected to acute alveolar hypoxia. Leukotrienes have also been found in tracheal washings of human newborns with persistent pulmonary hypertension (21). Although other pulmonary sources exist, virtually all of the leukotrienes contained in the lung can be manufactured within the mast cell (22). Activation of human lung mast cells by immunologic and nonimmunologic stimuli lead to quantitative differences in histamine release but result in release of similar quantities and types of arachadonic acid metabolites, predominantly $\mathrm{PGD}_{2}$ and $\mathrm{LTC}_{4}(23)$. Mast cell membrane activation leads to the release and metabolism of arachadonic acid $(23,24)$, a process that is dependent on changes in membrane permeability and calcium influx (24) just as is degranulation. By altering calcium influx, cromolyn sodium might alter the synthesis of certain mediators as well as block degranulation of preformed substances. Since hypoxia may upset the balance of vasoconstrictors and vasodilators that exists normally in the lung, the synthesis and release of vasoactive substances by lung mast cells during hypoxia and exposure to cromolyn sodium bears further investigation.

Acknowledgments. The authors acknowledge Mr. Thomas Sziszak and Ms. Cheryl Orintas for their excellent technical assistance, and Dr. Aaron Taub and Fison Corporation for generously providing the cromolyn sodium.

\section{REFERENCES}

1. Hyman AL, Kadowtiz PJ 1975 Effects of alveolar and perfusion hypoxia and hypercapnia on pulmonary vascular resistance in the lamb. Am J Physiol 228:397-403

2. Lewis AB, Heymann MA Rudolph AM 1976 Gestational changes in pulmonary vascular responses in fetal lambs in utero. Circ Res 39:536-541

3. Lloyd TC 1968 Hypoxic pulmonary vasoconstriction: role of perivascular tissue. J Appl Physiol 25:560-565

4. Haas F, Bergofsky EH 1972 Role of the mast cell in the pulmonary pressor response to hypoxia. J Clin Invest 51:3154-3162

5. Ahmed T, Oliver W, Frank B, Robinson M, Wanner A 1982 Hypoxic pulmonary vasoconstriction in conscious sheep: role of mast cell degranulation. Am Rev Respir Dis 126:291-297

6. Brogden RN, Speight TM, Avery GS 1974 Sodium cromoglycate (cromolyn sodium): A review of its mode of action, pharmacology, therapeutic efficacy and use. Drugs 7:164-282

7. Rudolph AM, Yuan S 1964 Response of the pulmonary vasculature to hypoxia 
and $\mathrm{H}+\mathrm{ion}$ concentration changes. J Clin Invest 45:399-411

8. Heymann MA 1984 Control of the pulmonary circulation in the perinatal period. J Dev Physiol 6:281-290

9. Winer BJ 1962 Single-factor experiments having repeated measures on the same elements. In: Statistical Principles in Experimental Design. McGrawHill Book Company, New York, pp 267-270

10. Zar JH 1974 Multiple comparisons. In: Biostatistical Analysis. Prentice-Hall, Inc., Englewood Cliffs, NJ, pp 151-153

11. Padawer J 1979 Mast cell structure: Implications for normal physiology and degranulation. In: Pepys J, Edwards AM (eds) The Mast Cell: Its Role in Health and Disease, University Park Press, Baltimore, pp 1-8

12. Cox JSG, Beach JE, Blair AMJN, Clark AJ, King J, Lee TB, Loveday DEE Moss GF, Orr TSC, Ritchie JT, Sheard P 1970 Disodium cromoglycate (Intal). Advan Drug Res 5:115

13. Ahmed T, Oliver W 1983 Does slow-reacting substance of anaphylaxis mediate hypoxic pulmonary vasoconstriction? Am Rev Respir Dis 127:566-571

14. Leffler CW, Mitchell JA, Green RS 1984 Cardiovascular effects of leukotrienes in neonatal piglets. Role in hypoxic pulmonary vasoconstriction? Circ Res 55:780-787

15. Rengo F, Trimarco B, Ricciardelli B, Volpe M, Violini R, Sacca L, Chiariello M 1979 Effects of disodium cromoglycate on hypoxic pulmonary hypertension in dogs. J Pharmacol Exp Ther 211:686-689

16. Kay JM, Grover RF 1975 Lung mast cells and hypoxic pulmonary hyperten- sion. Prog Respir Res 9:157-164

17. Doherty GB, Moorthi DS, Namsirikul P, Subramony D, Healy L, MacDonnell KF 1978 The effect of cromolyn sodium on hypoxia-induced histamine release. Ann Allergy 41:208-210

18. Martin LF, Tucker A, Munroe ML, Reeves JT 1978 Lung mast cells and hypoxic pulmonary vasoconstriction in cats. Respiration 35:73-77

19. Zhu YJ, Kradin R, Brandstetter RD, Staton G, Moss J, Hales CA 1983 Hypoxic pulmonary hypertension in the mast cell-deficient mouse. J Appl Physiol 54:680-686

20. Schreiber MD, Heymann MA, Soifer SJ 1985 Leukotriene inhibition prevents and reverses hypoxic pulmonary vasoconstriction in newborn lambs. Pediatr Res 19:437-441

21. Stenmark KR, James SL, Voelkel NF, Toews WH, Reeves JT, Murphy RC 1983 Leukotriene $C_{4}$ and $D_{4}$ in neonates with hypoxemia and pulmonary hypertension. N Engl J Med 309:77-80

22. MacGlashan DW, Schleimer RP, Peters SP, Shulman ES, Adams GK, Newball $\mathrm{HH}$, Lichtenstein LM 1982 Generation of leukotrienes by purified human lung mast cells. J Clin Invest 70:747-751

23. Peters SP, MacGlashan DW, Schulman ES, Schleimer RP, Hayes EC, Rokach $\mathrm{J}$, Adkinson NF, Lichtenstein LM 1984 Arachadonic acid metabolism in purified human lung mast cells. J Immunol 132:1972-1979

24. Schwartz LB, Austen KF 1984 Structure and function of the chemical mediators of mast cells. Prog Allergy 34:271-321 